\title{
Evaluation of the ground surface Enthalpy balance from bedrock temperatures (Livingston Island, Maritime Antarctic)
}

\author{
M. $\operatorname{Ramos}^{1}$ and G. Vieira ${ }^{2}$ \\ ${ }^{1}$ Department of Physics, University of Alcalá, 28871 Alcalá de Henares, Spain \\ ${ }^{2}$ Centre for Geographical Studies/Department of Geography, University of Lisbon, 1600-214 Lisbon, Portugal \\ Received: 22 February 2008 - Published in The Cryosphere Discuss.: 31 March 2008 \\ Revised: 15 April 2009 - Accepted: 11 May 2009 - Published: 26 May 2009
}

\begin{abstract}
The annual evolution of the ground temperatures from Incinerador borehole in Livingston Island (South Shetlands, Antarctic) is studied. The borehole is $2.4 \mathrm{~m}$ deep and is located in a massive quartzite outcrop with negligible water content, in the proximity of the Spanish Antarctic Station Juan Carlos I. In order to model the movement of the $0^{\circ} \mathrm{C}$ isotherm (velocity and maximum depth) hourly temperature profiles from: (i) the cooling periods of the frost season of 2000 to 2005 , and (ii) the warming periods of the thaw season of 2002-2003, 2003-2004 and 2004-2005, were studied. In this modelling approach, heat gains and losses across the ground surface are assumed to be the causes for the $0^{\circ} \mathrm{C}$ isotherm movement. A methodological approach to calculate the ground Enthalpy change based on the thermodynamic analysis of the ground during the cooling and warming periods is proposed. The Enthalpy change into the rock is equivalent to the heat exchange through the ground surface during each season, thus enabling to describe the interaction groundatmosphere and providing valuable data for studies on permafrost and periglacial processes. The bedrock density and thermal conductivity are considered to be constant and initial isothermal conditions at $0^{\circ} \mathrm{C}$ are assumed (based in collected data and local meteorological conditions in this area) to run the model in the beginning of each season. The final stages correspond to the temperatures at the end of the cooling and warming periods (annual minima and maxima). The application of this method avoids error propagation induced by the heat exchange calculations from multiple sensors using the Fourier method.
\end{abstract}

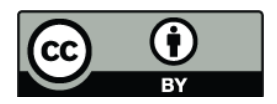

Correspondence to: M. Ramos (miguel.ramos@uah.es)

\section{Introduction}

\section{Climate change and permafrost in the Antarctic}

Mesoscale modelling results indicate that air temperature increase will be highest in the high latitudes, with rapid changes prone to occur in the Polar Regions (Anisimov et al., 1997; IPCC 2007, http://www.ipcc.ch/). In the Antarctic, the 50 last years of meteorological observations show that the climate variability was not homogenous. The climate of the Antarctic Peninsula region has experienced a major warming trend over the last 50 years with annual mean air temperatures at Faraday/Vernadsky having increased at a rate of $0.56^{\circ} \mathrm{C} /$ decade and $1.09^{\circ} \mathrm{C} /$ decade during the winter (King, 1994; Turner et al., 2005). In this region the surface mass balance of glaciers has increased at isolated sites (Peel, 1992), the number of winter precipitation events in Rothera has increased by 50\% (Turner et al., 1997), and a number of ice shelves have retreated and disintegrated (Vaughan and Doake, 1996; Scambos et al., 2003). Several factors contributing to the anomalous warming in the Antarctic Peninsula and the Weddell Sea region have been proposed, some of them related to the increase in westerlies wind observed over the last 30 years (Marshall, 2002).

Increasing air temperatures and precipitation may cause the degradation or even the disappearance of permafrost in, where current climatic conditions produce near-zero annual air temperatures, such as the South Shetland Islands, north of the Antarctic Peninsula.

The energy exchange between the ground surface and the atmosphere depends mainly on the radiation balance, ground heat fluxes and turbulent heat fluxes at the ground and snow surfaces. These are especially complex in the alpine and

Published by Copernicus Publications on behalf of the European Geosciences Union. 
polar maritime areas, where the relief is mountainous and snow cover influence is particularly strong (Van Lipzig et al., 2004; King and Turner, 1997; King et al., 2003). The seasonal snow cover, which presents a barrier to ground heat loss in winter, is a leading factor in the ground thermal regime and active layer thickness (Lachenbruch, 1959; Outcalt et al., 1975; Goodrich, 1982; Williams and Smith, 1989; Zhang et al., 1996; Romanosky and Osterkamp, 2000; Ling and Zhang, 2004). Snow has a high surface albedo and high emissivity, inducing cooling of its surface, while the low thermal conductivity makes it a good insulator. The ground heat flux is another important magnitude in the energy balance and the main factors that control it in permafrost terrain are: (i) ground thermal properties (ii) moisture content in the active layer, (iii) thaw effects at the free boundary, and (iv) non-conductive heat transfer effects (variable thermal diffusivity) (Romanovsky et al., 2000).

Compared to the Arctic where permafrost research developed accompanying engineering needs for regional socioeconomic development and natural resource exploitation, very little is known about Antarctic permafrost (Bockheim, 1995). In 2004 only 4 active layer boreholes were being monitored in the Antarctic Peninsula region and a number as small as 21 in the whole Antarctic Region (Bockheim, 2004). Complex logistical and maintenance problems and the remoteness of the Antarctic are the main causes for this scarcity. The limited knowledge of the ground temperature conditions led to a recent effort to increase active layer and permafrost research in the Antarctic under the framework of international programs. Two core projects of the International Polar Year 2007-2008 where Antarctic permafrost plays a central role are under way: ANTPAS - Antarctic and Sub-Antarctic Permafrost, Soils and Periglacial Environments and TSP - Permafrost Observatory Project - Thermal State of Permafrost (Guglielmin et al., 2003; Bockheim, 2004). The present research is integrated in these projects and intends to monitor and model the active layer temperature regime in a shallow borehole in Livingston Island (South Shetland Islands, Antarctic Peninsula) (Ramos and Vieira, 2003).

The objective of this paper is to present a one-dimensional stationary heat transfer equilibrium model without phasechange developed to calculate the seasonal energy balance (Enthalpy) of the ground-atmosphere interface during the annual periods of ground warming and cooling. The methodology is based on the measurements of the temperature gradient evolution in a shallow borehole in bedrock. For modelling purposes we consider that the bedrock has negligible water content and that there is no advective heat transfer. Therefore, phase-change effects are not included in the modelling. These assumptions are valid due to the massive bedrock at the borehole site.

\section{Study area}

\subsection{Geological and geomorphological setting}

Hurd Peninsula is a mountainous area located in the south coast of Livingston Island, South Shetlands, Antarctic $\left(62^{\circ} 39^{\prime} \mathrm{S}, 60^{\circ} 21^{\prime} \mathrm{W}\right)$. About $90 \%$ of the island is glaciated with ice-free areas occurring at low altitude, generally in small but rugged relief peninsulas. The study focuses on the ice-free areas of the north western part of Hurd Peninsula in the vicinity of the Spanish Antarctic Station (SAS) Juan Carlos I (Fig. 1). The borehole where ground data is collected is located at $35 \mathrm{~m}$ a.s.l. at Incinerador Point.

The bedrock is a low-grade metamorphic turbidite sequence with alternating layers of fine sandstones and shales, with conglomerates and breccias in some areas (Miers Bluff Formation - Arche et al., 1992). The succession dips $45^{\circ} \mathrm{NW}$ and is affected by open folds, mainly overturned (Pallàs, 1996). Dolerite dykes and quartz veins are frequent (Arche et al., 1992). The surficial lithology is very heterogeneous inducing different weathering styles and products.

During Marine Isotope Stage 2 Livingston Island was covered by an extensive ice-cap. It was only in the Holocene that deglaciation started and most ice-free areas of the peninsulas became ice-free only after ca. $6.4 \mathrm{ka}$ BP. Two glacier advances have been reported for the Holocene, the first between 720 and $330 \mathrm{BP}$ and the other after $300 \mathrm{BP}$. This has been interpreted as correlative to the Little Ice Age (Pallàs, 1996). Glaciers are retreating steadily today.

\subsection{Climate}

The circum-Antarctic low-pressure system controls the climate, which is cold-oceanic with frequent summer rainfall at low altitudes and moderate annual temperature range. Relative humidity is very high with average values from 80 to $90 \%$ (Simonov, 1977; Styszynska, 2004). Mean annual air temperatures in the Antarctic Peninsula region vary between $-5.2^{\circ} \mathrm{C}$ (Esperanza) and $-1.6^{\circ} \mathrm{C}$ (Arctowski) and annual precipitation is ca. $500 \mathrm{~mm}$ (http://www.antarctica.ac. uk/met/READER/surface/stationpt.html) (King, 1994).

Continuous meteorological series for Livingston Island are lacking. Air temperature data from loggers installed at a 15, 165 and $275 \mathrm{~m}$ a.s.l in the study area show mean annual air temperatures from 2003 to 2005 of -1.5 to $-3.0^{\circ} \mathrm{C}$. From April to November mean daily air temperatures are generally frost and from December to March temperatures are slightly positive (Fig. 2). Two contrasting seasons in what concerns to the ground temperature regime above $0^{\circ} \mathrm{C}$ (thaw season) or frost season (below $0^{\circ} \mathrm{C}$ ) are well-defined.

Snow cover data is absent for the study areas, but the ground surface temperature data suggests a high interannual variability. Generally snow covers the ground from April to December, with decimetrical thickness. Shallower depths are found in wind swept sites. 


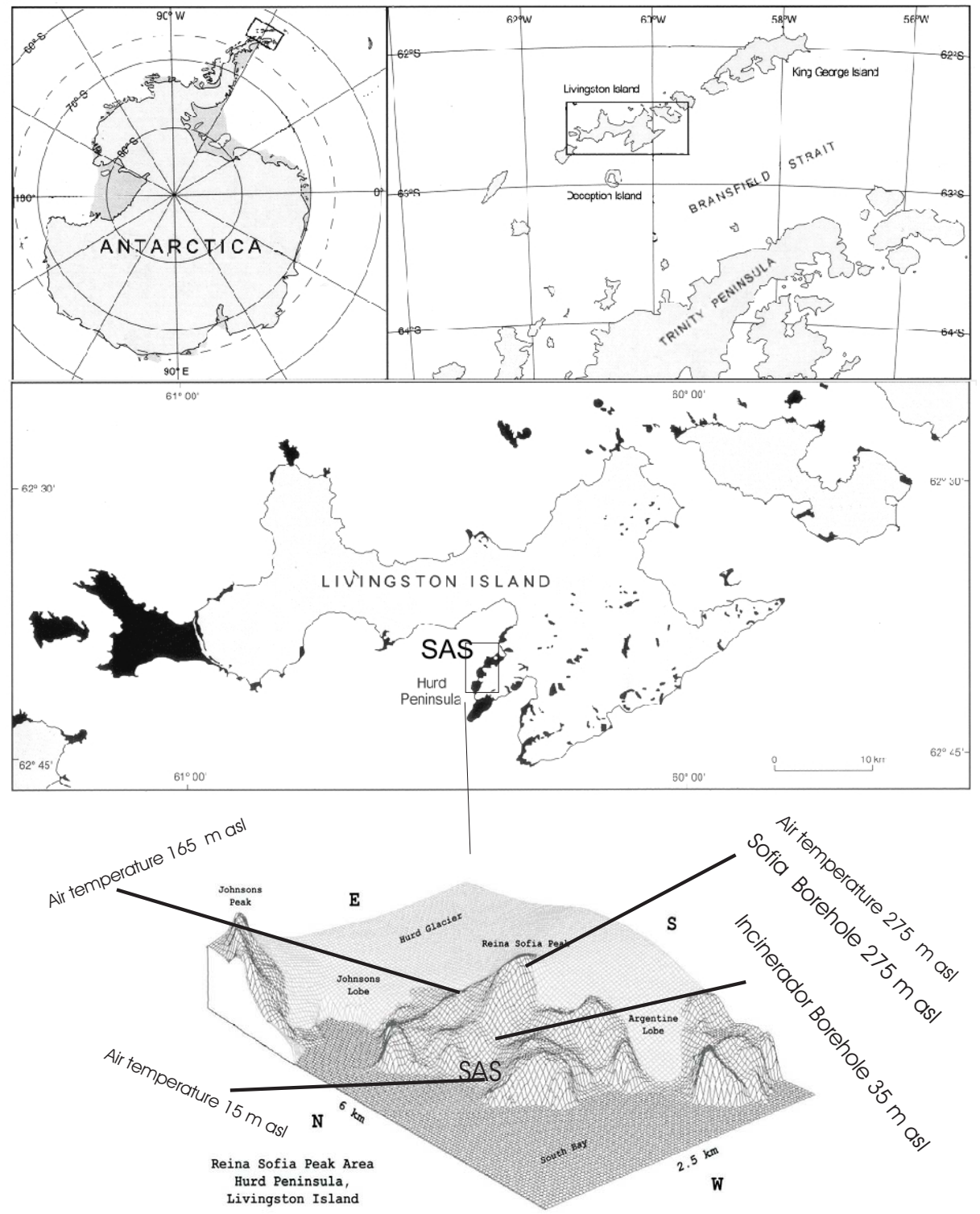

Fig. 1. Location of the study area in Livingston Island. SAS - Spanish Antarctic Station Juan Carlos I. The black area shows the snow free terrain in summer (adapted from López-Martínez et al., 1992).

\subsection{Permafrost distribution}

Permafrost distribution in Livingston Island has been studied using geomorphological evidence (Serrano and LopezMartinez, 2000; Vieira and Ramos, 2003), ground temperature monitoring in shallow boreholes (Ramos and Vieira, 2003; Ramos et al., 2007) and geophysical surveying (Hauck et al., 2007). Geomorphological and geophysical observations indicate that permafrost occurs immediately above sea-level associated to ice-cored moraines and rock glaciers, but in bedrock terrain its identification is more complex. Borehole data and excavations at Reina Sofia Hill
(275 $\mathrm{m}$ a.s.l.) show the presence of permafrost with more than $25 \mathrm{~m}$ depth and an active layer ca. $90 \mathrm{~cm}$ thick in boulderly diamicton.

\section{Methodology}

\subsection{Shallow borehole temperature data}

This study focus on data from a shallow borehole installed in the vicinity of the Spanish Antarctic Station Juan Carlos $\mathrm{I}$ at Incinerador Point (35 m a.s.1.). The borehole is $2.4 \mathrm{~m}$ deep and is drilled in massive quartzite (very high thermal 
Mean daily air and ground temperatures at Spanish Antarctic Station JCI

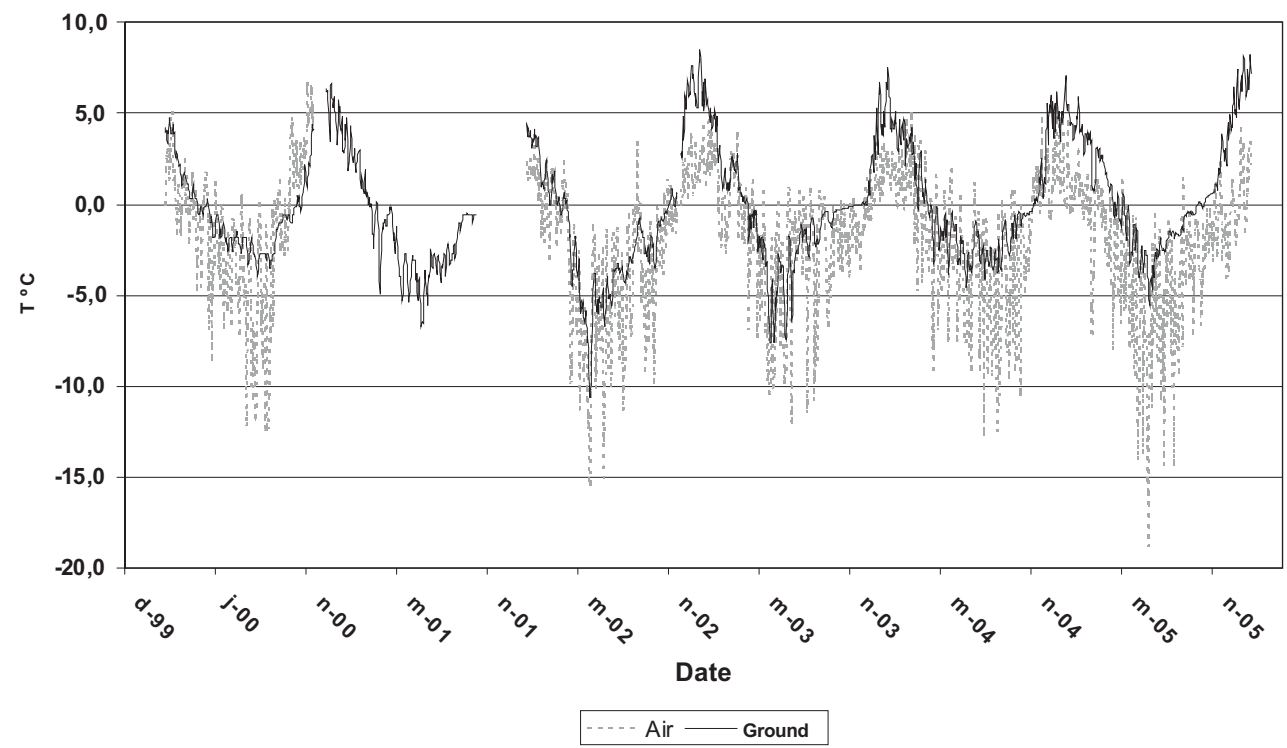

Fig. 2. Mean daily ground temperature at $15 \mathrm{~cm}$ depth into Incinerador borehole and air temperature at the Spanish Antarctic Station (15 $\mathrm{m}$ a.s.1.) from 2000 to 2005 .

diffusivity and low porosity) showing only minor joints. The topographical position of the borehole in a small step reduces the possibility of water flow along the joints and the convex shape of the outcrop also diminishes the water presence in the joints. The absence of freezing curtain effects in the temperature series supports the negligible effect of ground moisture. The bedrock is exposed to the surface and no vegetation occurs at the study site, neither in its vicinity.

The borehole is cased with a plastic cylinder $90 \mathrm{~mm}$ in diameter. Ground temperatures at different levels are recorded at hourly intervals since 2000, but only after 2003 continuous annual temperature series were recorded. Miniature single-channel data loggers (Tiny Talk (Gemini Co.)) with a NTC-10 K thermistor with a resolution better than $0.05^{\circ} \mathrm{C}$ and an accuracy of 0.1 to $0.2^{\circ} \mathrm{C}$ have been used. It was not possible to install a large number of temperature sensors in 2000 and only in the subsequent years the number was increased. This fact and a problem in the reinstallation of the chain in 2003 gave origin to changes of measuring depths during the initial period.

In the slopes near the Incinerador borehole at ca. $20 \mathrm{~m}$ a.s.1. frozen ground has been found in talus materials (Bergamin et al., 1997) suggesting that permafrost in bedrock may also be present. Geophysical surveying in bedrock at the borehole site using 2-D electrical tomography resistivity, ground penetrating radar and refraction seismics were inconclusive in what concerns to detecting the presence of rich ice permafrost (Hauck et al., 2007). The borehole temperatures show an annual cycle with a clear period of temperatures below $0^{\circ} \mathrm{C}$ and another of thaw (above $0^{\circ} \mathrm{C}$ ). These are defined here as the frost and the thaw seasons. In the borehole and in the modelling approach, they are assumed to be related to the presence of a thick active layer controlled by the high diffusivity of quartzite.

Ground temperature data from 2000 to 2005 illustrate the significant control caused by the type of substratum on the active layer thickness as shown also by other authors in different regions (Washburn, 1979; Williams and Smith, 1989; French, 1996; Hoelzle et al., 2001). At Incinerador borehole, drilled in quartzite bedrock, a lithology showing high thermal diffusivity (density $-2650 \mathrm{~kg} / \mathrm{m}^{3}$, specific heat $-720 \mathrm{~J} / \mathrm{kgK}$, thermal diffusivity $-1.23 \times 10^{-6} \mathrm{~m}^{2} / \mathrm{s}$, thermal conductivity $-2.35 \mathrm{~W} / \mathrm{mK}$ - Schön, 1996) and negligible water content at this site, there is no zero-curtain effect related to latent heat exchange (Figs. 2 and 3). At this site, with a mean annual air temperature close to $-2^{\circ} \mathrm{C}$, mean annual ground temperatures in the borehole show values between $-0.1^{\circ} \mathrm{C}$ at $15 \mathrm{~cm}$ and $0.1^{\circ} \mathrm{C}$ at $230 \mathrm{~cm}$ depth. This indicates that the site is near the limit of permafrost and the ground temperatures are close to $0^{\circ} \mathrm{C}$. Given the bedrock physical properties, the estimated active layer thickness is in the order of 2 to $5 \mathrm{~m}$.

Despite not having temperature data below the borehole depth, our assumption of nearly isothermal conditions at $0^{\circ} \mathrm{C}$ at depth is supported by modelling of ground temperatures. The application of the alternative solution to the Stephan problem as proposed by Kudryavtsev et al. (1974) results on temperature values at depth of $0^{\circ} \mathrm{C}$. Similarly, the application of the TTOP modelling approach (Smith and Riseborough, 1996) results in values close to $-0.3^{\circ} \mathrm{C}$. 


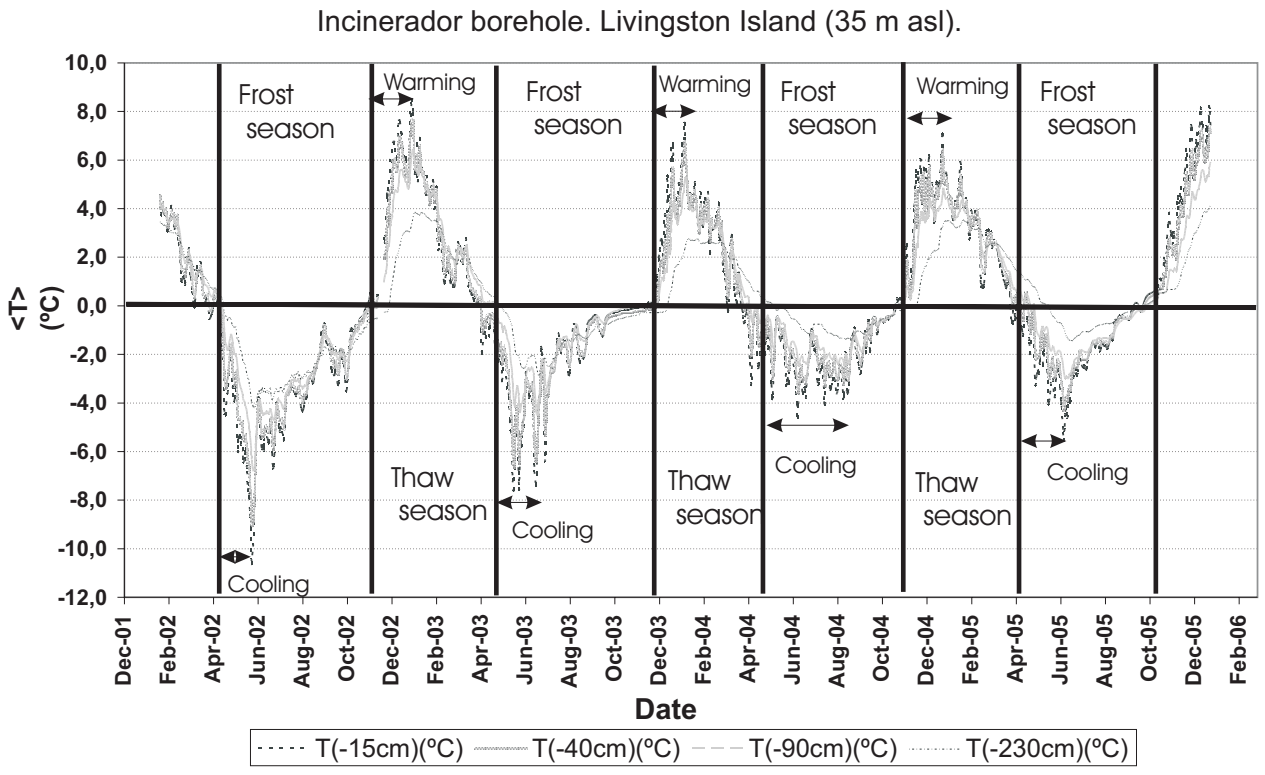

Fig. 3. Definition of the periods of cooling during the frost season $\left(t_{c f}\right)$ and warming during the thaw season $\left(t_{w t}\right)$. The cooling and the warming seasons start when the thermal gradient is constant and close to $0^{\circ} \mathrm{C} / \mathrm{m}$.

\subsection{Enthalpy change modelling}

Temperature records from the Incinerador borehole for the winters of 2001 to 2005 and for the summers of 2002 to 2005 were used (Fig. 3). These data enable calculating: (i) the Enthalpy change (equivalent to the heat exchanged with the atmosphere through the ground surface during the frost and thaw seasons), and (ii) the rates of cooling and warming of the ground (equivalent to the rate of heat exchanged per unit of time through the ground surface during the frost and thaw seasons). The frost season is defined here as the period when ground temperatures remain below $0^{\circ} \mathrm{C}$ and the thaw season as the period with ground temperatures above $0^{\circ} \mathrm{C}$. The $0^{\circ} \mathrm{C}$ isotherm position and rate of movement are used to estimate the duration of the frost and thaw seasons.

The ground Enthalpy change in the periods of cooling during the frost season corresponds to the heat loss through the ground surface. This energy parameter is a function of the thermodynamical processes of energy exchange between ground and air (e.g. ground heat flux, sensible heat flux, turbulent fluxes, radiation balance and snow layer variability). In a similar way, the ground Enthalpy during the thaw season in the period of warming is the heat gained by the ground across its surface.

The ground thermodynamic variables needed to calculate the Enthalpy change are: (i) ground thermal diffusivity $(\alpha)$, (ii) thermal conductivity (K), (iii) density $(\rho)$ and (iv) heat capacity (C) (Ramos and Vieira, 2004).

The thermal diffusivity $(\alpha)$ was calculated experimentally from the ground temperature gradient in episodes with sinusoidal signal using harmonic temperature analysis (Stearns,
1965; Deacon, 1969; Zhang et al., 1996). This was achieved using an inverse analysis with the steady-state solution of the heat equation for a semi-infinite system with sinusoidal temperature conditions at the surface. The non-conductive factors associated with non-porous heat transfer in bedrock were considered negligible due to the massive character of the bedrock (e.g. Hinkel et al., 1990; Kane et al., 2001). The thermal diffusivity obtained for the two seasons show a small range $\left(\alpha=1.23 \pm 0.2 \times 10^{-6} \mathrm{~m}^{2} / \mathrm{s}\right)$ (Ramos and Vieira, 2004) and are in agreement with the tabulated limits values for quartzite (Schön, 1996). Therefore the tabulated data for thermal conductivity, density and specific heat capacity were used.

The ground surface heat flux exchange is a key parameter for studying the interactions between the ground and the atmosphere boundary layer (Oke, 1987; Williams and Smith, 1989). The proposed approach is based on the following assumptions: (i) the ground acts as a homogeneous mean (massive rock) with constant density and semi-infinite geometry (one-dimensional heat transfer problem), (ii) the temperatures at some depth below the borehole are stable and close to $0^{\circ} \mathrm{C}$, and (iii) heat transfer in the ground occurs only through the surface. This system is characterised and corresponds to the equilibrium model category as presented by Riseborough et al. (2008).

The ground Enthalpy balance $(\Delta \mathrm{H})$, in this case, is equivalent to the change in internal Energy of the ground between two thermodynamic states $(\Delta \mathrm{U})$. Enthalpy change equation is:

$$
\Delta \mathrm{H}=\Delta \mathrm{U}+\mathrm{P} \Delta \mathrm{V}+\mathrm{V} \Delta \mathrm{P}
$$


Zero Isotherm front during winter 2003

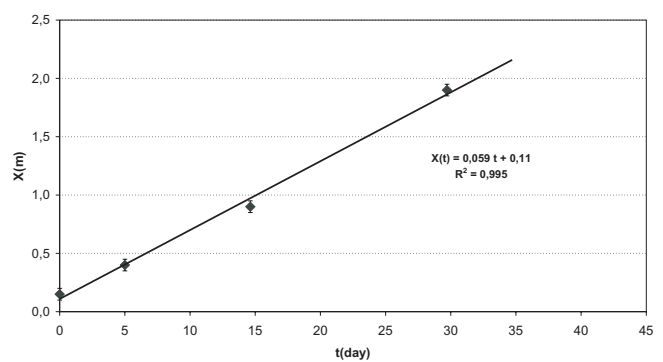

Zero Isotherm front during summer 2003-04

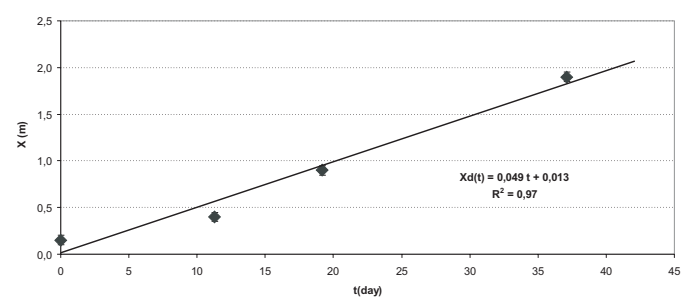

Zero Isotherm front during summer 2004-05

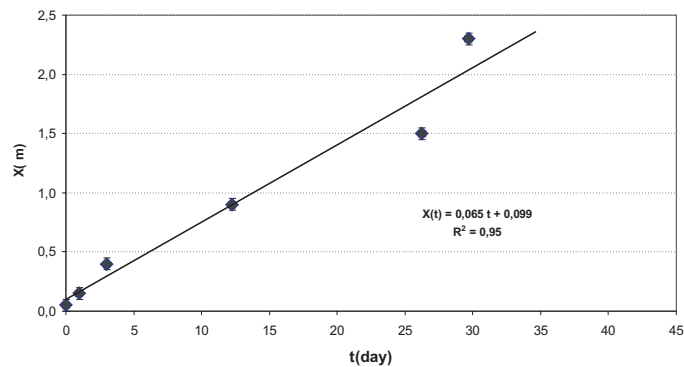

Zero Isotherm front during winter 2005

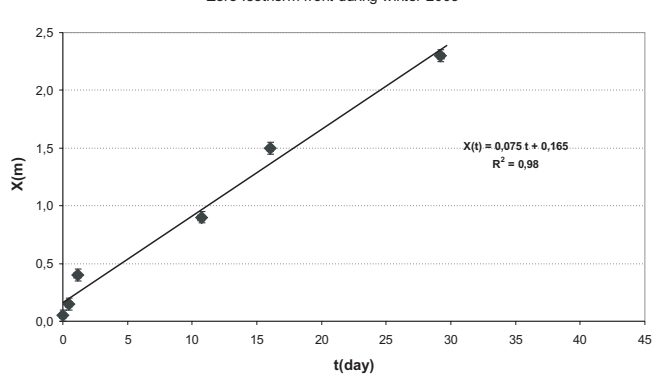

Fig. 4. Penetration of the $0^{\circ} \mathrm{C}$ isotherm during the winters of 2003, 2005 and summers 2003-2004, 2004-2005 at the Incinerador borehole. The best-fit equation is used to estimate the maximum depth of penetration of the zero isotherm front during cooling and warming, $D_{f-t}$.

But since non appreciable volumetric change takes places (constant ground density) and since the pressure is constant, Enthalpy change is equal to the ground internal Energy.

$\Delta \mathrm{H}=\Delta \mathrm{U}$
This function corresponds to the heat exchange at the ground-atmosphere boundary layer interface, since energy exchanges occur across the ground surface. The signal is positive if the ground gains energy and negative if it looses energy.

The annual evolution of the ground temperature profiles at the Incinerador borehole show two distinct periods: (i) the frost season, when the temperature profile is below $0^{\circ} \mathrm{C}$ $\left(T(x)<0{ }^{\circ} \mathrm{C}\right)$, (ii) the thaw season, when the temperature profile is thaw $\left(T(x)>0{ }^{\circ} \mathrm{C}\right)$.

In the autumn the ground looses energy and active layer temperatures fall frost with a slight delay in depth. These conditions last until spring, when due to the net gain of energy, the temperatures of the active layer rise above $0^{\circ} \mathrm{C}$ and the thaw season starts. Inside each of these two seasons, two periods marked by net ground heat loss or gain can be identified. In our calculations these periods are especially significant and they are defined as (Fig. 3): (i) the period of cooling in the frost season $\left(t_{c f}\right)$, when $T(\mathrm{x})<0^{\circ} \mathrm{C}$ and the ground loses energy; (ii) the period of warming in the thaw season $\left(t_{w t}\right)$, when $T(\mathrm{x})>0^{\circ} \mathrm{C}$ and the ground gains energy.

During the period of cooling in the frost season $\left(t_{c f}\right)$, the heat lost by the ground through its surface $S$ (per $\mathrm{m}^{2}$ ) is equivalent to the ground Enthalpy change throughout the same interval and surface $\left(\Delta \mathrm{H}_{f} / \mathrm{S}\right)$. The continuous heat flow from depth towards the surface during cooling $\left(t_{c f}\right)$ is the average thermal heat flux:

$<\Phi_{f}>=\Delta \mathrm{H}_{f} /\left(\mathrm{S} t_{c f}\right)$

In the period of ground warming in the thaw season $\left(t_{w t}\right)$, the ground will gain heat through its surface $\left(\Delta \mathrm{H}_{t} / \mathrm{S}\right)$ and its average thermal flux is:

$<\Phi_{t}>=\Delta \mathrm{H}_{t} /\left(\mathrm{S} t_{w t}\right)$.

There are two classical methods in the simplest onedimensional heat conduction problem to calculate the ground Enthalpy change (Arya, 1988). One is to use Fourier's law to calculate the rate of heat transfer or heat flux in the vertical (x) direction:

$H_{G}=-K\left(\frac{\partial T}{\partial x}\right)$

The other method to determine the ground surface heat flux using the ground temperature gradient is based in the law of conservation of energy into the ground medium. If there are no sources or sinks of energy (this is the case in our problem) the net rates of heat flowing in volume should equal the rate of change of internal energy in volume, then:

$\frac{\partial}{\partial t}(\rho c T(z, t))=\frac{\partial H_{G}}{\partial z}$

This equation, by means of the energy balance equation, is often used to determine the ground heat flux $\left(H_{G}\right)$ from measurements of ground temperatures as a function of time. The 
method is based in the integration of the Eq. (6) from $z=0$ (ground surface) to $D$, where $D$, is a reference depth where ground heat flux is zero. In our study case this corresponds to the maximum or minimum penetration of the $0^{\circ} \mathrm{C}$ isotherm during the cooling or warming seasons.

$H_{G}=\int_{0}^{D} \frac{\partial}{\partial t}(\rho c T(z, t)) d z$

To apply accurately these procedure numerous sensors in the ground and a high precision of differential temperature records are needed. Otherwise, the global error in the energy estimation would be too high. This limitation is linked to the problems arising from the sums of the differences of the instantaneous temperatures. If the method is applied to a scarce number of ground temperature sensors, the accumulative rate of error is done by an integral procedure. In our experimental study the temperature sensor chain is based in non-differential measurements and consists of only 6 thermistor probes with and standard accuracy of $0.2^{\circ} \mathrm{C}$.

If we transform the Eq. (7) in a finite solution using the temperature profile readings with a $t_{R}$ measuring period, assuming $(\rho \mathrm{c})$ well known and constant with time:

$H_{G}=\rho c \sum_{i=1}^{6} \frac{\left[T_{i}\left(t+t_{R}\right)-T_{i}(t)\right]}{t_{R}} z_{i}$

An error analysis was conducted to evaluate the method and the accumulative contribution of the terms due to the instrumental error on temperatures, considering negligible the error contribution of time and position, has the following expression:

$\Delta H_{G}=\frac{\rho c}{t_{R}} \sum_{i=1}^{6}\left[\Delta T_{i}\left(t+t_{R}\right)-\Delta T_{i}(t)\right] z_{i}$

In a detailed analysis we can see that the differences between temperatures at two consecutives times (the measuring period was $30 \mathrm{~min}$ ) have a similar order of magnitude to the instrumental accuracy. Furthermore, the absolute error increases enormously with time when global heat flux exchange during the cooling or warming seasons is calculated by integral procedure (Table 1). The technical solution to reduce the error is to measure with a differential system for temperature, with a very well calibrated reference thermal system and a large number of sensors. These conditions are not compatible with the characteristics of the Antarctic monitoring sites, that were isolated in very rough meteorological conditions all year-long.

With a small number of sensors in the borehole, as in the present situation (4 sensors in 2001, 2002 and 2003 and 6 sensors in 2004 and 2005) and as it is the case of most shallow boreholes, a more robust method supported by thermodynamic arguments, like the Enthalpy method presented here will provide better results. This is guiding line of this paper, that focus on the Enthalpic method enabling a more accurate way to calculate the global energy exchange across the ground surface during two characteristics periods (winter and summer).

In the current approach, we consider that near the start of the cooling period in the frost season $\left(t_{c f}\right)$ the ground temperature state is isothermal at $0^{\circ} \mathrm{C}$. This is an adequate hypothesis since all the sensors are very close to this initial thermal equilibrium state at the initial condition and we can assume that there is a thermodynamic equilibrium at the initial state (i): $T_{i f}(\mathrm{x})=0^{\circ} \mathrm{C}$ (initial state in the frost season $-\mathrm{i}$ ). During the period of cooling in the frost season (determined from the temperature data), the ground looses heat until it reaches a final state $(\mathrm{F})$ of minimum energy $\left(T_{F}(\mathrm{x})\right)$, characterized by the depth profile of the minimum temperatures $\left(T_{F f}(\mathrm{x})=\mathrm{T}_{\min }(\mathrm{x})\right)$. In the period of warming during the ground thaw season $\left(t_{w t}\right)$ the initial state (i) is also $T_{i t}(\mathrm{x})=0^{\circ} \mathrm{C}$. The final state $(\mathrm{F})$ corresponds to the depth distribution of the maximum temperatures $\left(T_{F t}(\mathrm{x})=T_{\mathrm{Max}}(\mathrm{x})\right.$.)

To estimate the heat flow during these periods, the Enthalpy change in the active layer between the initial (i) and final (F) equilibrium states is calculated. The hourly records of the temperature profiles are used to determine the initial and final states in both the warming and cooling periods.

On the other hand, the analysis of the temperature regimes at different depths allows estimating the penetration of the $0{ }^{\circ} \mathrm{C}$ isotherm versus time (respectively, $\mathrm{X}_{f}(\mathrm{t})$ in the frost season and $\mathrm{X}_{t}(\mathrm{t})$ in the thaw season). The velocities of the migration of the zero isotherm (slope of $\mathrm{X}_{f-t}(\mathrm{t})=\mathrm{dX} \mathrm{X}_{f-t} / \mathrm{dt}$ $(\mathrm{m} /$ day $))$ are assumed to be constant and a linear fit is used. Figure 4 shows an example for estimating $\mathrm{X}_{f}(\mathrm{t})$ during the periods of cooling $\left(t_{c f}\right)$ in the frost seasons 2003 and 2005 and $\mathrm{X}_{t}(\mathrm{t})$ during warming in the frost seasons of 2003-2004 and 2004-2005 $\left(t_{w t}\right)$.

These linear fits enable the estimation of the maximum active layer depth, $D_{f-t}$, showing the $0^{\circ} \mathrm{C}$ isotherm:

Cooling period : $D_{f}=X_{f}\left(t_{c f}\right)=m_{f} t_{c f}+n_{f}$

Warming period : $D_{t}=X_{t}\left(t_{w t}\right)=m_{t} t_{w t}+n_{t}$

Following the assumptions indicated above, $D_{f-t}$ corresponds to the depth of zero annual temperature range, where ground heat flux is zero that in this case correspond to the $0^{\circ} \mathrm{C}$ uniform ground temperature.

The experimental temperature profiles in the final states were calculated for each sensor depth for the winters of 2001, 2002, 2003, 2004 and 2005 and also for the summers of 2002-2003, 2003-2004 and 2004-2005 (Figs. 5 and 6). Logfit functions (12) applied to the final (maximum and minimum) temperature profiles show a good agreement with the results. In both seasons, the area between the logarithmic fit and the $\mathrm{x}$-axis is function of the change of ground Enthalpy between the initial isothermal condition (i) and the final stage (F).

$T_{F}(x)=T_{\min -\operatorname{Max}}(x)=a \ln x-b$ 
Table 1. In the table we present the result of the energy balance in 2004 over the two seasons using our Enthalpic method and the standard one.

\begin{tabular}{llll}
\hline 2004 (frost) & 2004 (frost) & 2004 (thaw) & 2004 (thaw) \\
\hline $\begin{array}{l}\text { Enthalpic method } \\
\left(\mathrm{MJ} / \mathrm{m}^{2}\right)\end{array}$ & Standard method & Enthalpic method & Standard method \\
$-16.3 \pm 2$ & $\left(\mathrm{MJ} / \mathrm{m}^{2}\right)$ & $\left(\mathrm{MJ} / \mathrm{m}^{2}\right)$ & $\left(\mathrm{MJ} / \mathrm{m}^{2}\right)$ \\
\hline
\end{tabular}

Table 2. Calculated values of ground Enthalpy change, ground heat fluxes, freezing indexes, air temperatures and duration of frost and thaw seasons for the Incinerador borehole (2000 to 2005).

\begin{tabular}{|c|c|c|c|c|c|c|c|c|c|c|}
\hline & & $\begin{array}{r}2000 \\
\text { (Frost) }\end{array}$ & $\begin{array}{r}2001 \\
\text { (Frost) }\end{array}$ & $\begin{array}{r}2002 \\
\text { (Frost) }\end{array}$ & $\begin{array}{r}2002-2003 \\
\text { (Thaw) }\end{array}$ & $\begin{array}{r}2003 \\
\text { (Frost) }\end{array}$ & $\begin{array}{r}2003-2004 \\
\text { (Thaw) }\end{array}$ & $\begin{array}{r}2004 \\
\text { (Frost) }\end{array}$ & $\begin{array}{r}\text { 2004-2005 } \\
\text { (Thaw) }\end{array}$ & $\begin{array}{r}2005 \\
\text { (Frost) }\end{array}$ \\
\hline $\begin{array}{l}\text { Modelled zero } \\
\text { isotherm depth }\end{array}$ & $\mathrm{D}_{f-t}(\mathrm{~m})$ & - & 7.7 & 7.2 & 3.8 & 4.2 & 3.6 & 5.6 & 4.6 & 2.6 \\
\hline \multirow{2}{*}{$\begin{array}{l}\text { Ground cooling in frost } \\
\text { season and warming in thaw season }\end{array}$} & $t_{c f-w t}\left(\mathrm{~s} \cdot 10^{6}\right)$ & - & 8.57 & 3.44 & 5.88 & 6.05 & 6.31 & 9.31 & 6.00 & 2.76 \\
\hline & $t_{c f-w t}$ (days) & - & 99 & 40 & 68 & 70 & 73 & 108 & 69 & 32 \\
\hline \multirow{2}{*}{ Energy } & Enthalpy/S $\left(\mathrm{J} / \mathrm{m}^{2} \cdot 10^{-7}\right)$ & - & -3.24 & -4.81 & 2.95 & -2.53 & 2.53 & -1.63 & 2.91 & -1.26 \\
\hline & Heat flux $\left(\mathrm{W} / \mathrm{m}^{2}\right)$ & - & -3.78 & -13.98 & 5.03 & -4.18 & 4.00 & -1.75 & 4.85 & -4.57 \\
\hline \multirow{5}{*}{ Freezing Indexes ( ${ }^{\circ}$ Cday) } & $\mathrm{I}_{a f}$ and $\mathrm{I}_{a t}$ & 657 & - & 1027 & 198 & 730 & 158 & 781 & 164 & 1102 \\
\hline & $\mathrm{I}_{f}(-5)$ and $\mathrm{I}_{t}(-5)$ & - & - & - & - & - & - & 420 & 490 & 354 \\
\hline & $\mathrm{N}-$ Factor $\left(\mathrm{I}_{f-t}(-15) / \mathrm{I}_{a f-t}\right)$ & 0.50 & - & 0.70 & 2.38 & 0.62 & 2.38 & 0.51 & 3.33 & 0.27 \\
\hline & $\mathrm{I}_{f}(-15)$ and $\mathrm{I}_{t}(-15)$ & $330^{*}$ & $536^{*}$ & 721 & 475 & 450 & 379 & 400 & 505 & 299 \\
\hline & $\mathrm{I}_{f}(-230)$ and $\mathrm{I}_{t}(-230)$ & 149 & 274 & 474 & $331^{* *}$ & 261 & 245 & 139 & 381 & 92 \\
\hline \multirow{3}{*}{ Air Temperature $\left({ }^{\circ} \mathrm{C}\right)$} & Mean & -3.1 & -2.3 & -4.2 & 1.5 & -2.7 & 1.2 & -3.5 & 0.9 & -3.4 \\
\hline & Minimum & -12.4 & -14.7 & -15.4 & -2.7 & -11.9 & -4.7 & -12.6 & -7.2 & -18.8 \\
\hline & Maximum & 1.8 & - & 3.4 & 4.7 & 1.5 & 5.1 & 2.9 & 5.2 & 2.3 \\
\hline \multirow{3}{*}{ Seasonality $(190 / 230 \mathrm{~cm}$ depth) } & Length (days) & $186^{* * *}$ & $236^{* * *}$ & 227 & 151 & 229 & 145 & $197^{* * *}$ & 183 & $134^{* * *}$ \\
\hline & Start (date) & 04-06-00 & 01-05-01 & 09-05-02 & $22-12-02$ & $22-05-03$ & 07-01-04 & $30-05-04$ & $11-12-04$ & 11-06-05 \\
\hline & End (date) & $07-12-00$ & $23-12-01$ & $22-12-02$ & $22-05-03$ & 06-01-04 & $31-5-04$ & $13-12-04$ & $12-6-05$ & $23-10-05$ \\
\hline
\end{tabular}

* Data at $25 \mathrm{~cm}$ depth, ${ }^{* *}$ Data at $190 \mathrm{~cm}$ depth, ${ }^{* * *}$ Data at $230 \mathrm{~cm}$ depth.

The infinitesimal change of Enthalpy in the system is defined by:

$d H_{f-t}=m c_{P} d T$

The change of Enthalpy $(\Delta \mathrm{H})$ is calculated from the temperature profiles defining the initial (i) and final (F) equilibrium states. For this purpose, the ground is divided in infinitesimal elements of thickness, $d x$, each of them experiencing a thermodynamic transformation from the initial state $\left(T_{i}(\mathrm{x})=0^{\circ} \mathrm{C}\right)$ to the final state accounting for its depth in the profile $\left(T_{F}(\mathrm{x})=T_{\min -\operatorname{Max}}(\mathrm{x})\right)$, choosing the minima for the frost and the maxima for the thaw seasons (11):

$$
d H_{f-t}=\rho S c_{P} d x\left[T_{F}(x)-T_{i}\right]
$$

The Enthalpy contribution of all the ground levels is calculated by integration along the maximum penetration of the zero isotherm fronts, $D_{f-t}$ :

$$
\int_{T_{i}}^{T_{F}} d H_{f-t}=\rho S c_{P} \int_{0}^{D_{f-t}}\left[T_{F}(x)-T_{i}\right] d x
$$

The value of $\Delta \mathrm{H} / \mathrm{S}$ is represented by the area between the $\log$-function representing $T_{F}(\mathrm{x})=T_{\min -\operatorname{Max}}(\mathrm{x})$ and the axis $T_{i}(\mathrm{x})=0{ }^{\circ} \mathrm{C}$.

$$
\begin{aligned}
& \frac{\Delta \mathrm{H}_{f-t}}{S}=\rho c_{P} \int_{0}^{D_{f-t}}\left(T_{F}(x)-T_{i}\right) d x \\
& =\rho c_{P} \int_{0}^{D_{f-t}}(a \ln x-b) d x
\end{aligned}
$$

Where, $D_{f-t}$ is the maximum depth of the zero isothermal front during frost $\left(t_{c f}\right)$ or thaw $\left(t_{w t}\right)$ periods, and $a$ and $b$ are constants representing the final state of equilibrium in the log-fit of the minimum and maximum temperatures profiles (in the frost and thaw season). To calculate the Enthalpy change per unit area, Eq. (16) is integrated to provide the following exact solution:

$$
\begin{aligned}
& \frac{\Delta \mathrm{H}_{f-t}}{S}=\frac{K}{\alpha} \int_{0}^{D_{f-t}}(a \ln x-b) d x \\
& =\frac{K D_{f-t}}{\alpha}\left[a \ln D_{f-t}-a-b\right]
\end{aligned}
$$


Table 3. Mean values (and standard deviations) of the modelled thermodynamic parameters for the active layer in three consecutive frost and thaw seasons in the period of 2003-2005.

\begin{tabular}{lrr}
\hline & Frost season & Thaw season \\
\hline $\mathrm{D}_{f t}(\mathrm{~m})$ & $4.1(1.5)$ & $4.0(0.6)$ \\
$\mathrm{t}_{c f}$ and $\mathrm{t}_{w t}(\mathrm{~s})$ & $6.03 \times 10^{6}\left(2.94 \times 10^{6}\right)$ & $6.06 \times 10^{6}\left(0.2 \times 10^{6}\right)$ \\
$\mathrm{t}_{c f}$ and $\mathrm{t}_{w t}($ days $)$ & $70(34)$ & $71(3)$ \\
Enthalpy $/ \mathrm{S}\left(\mathrm{J} / \mathrm{m}^{2}\right) \Delta \mathrm{H}_{f-t} / \mathrm{S}$ & $-1.81 \times 10^{7}\left(0.65 \times 10^{7}\right)$ & $2.80 \times 10^{7}\left(0.2 \times 10^{7}\right)$ \\
Heat Flux $\left(\mathrm{W} / \mathrm{m}^{2}\right)<\Phi_{c f-w t}>$ & $-3.5(1.5)$ & $4.6(0.5)$ \\
$\mathrm{Ia}\left({ }^{\circ} \mathrm{Cday}\right)$. & $871(202)$ & $173(22)$ \\
$\mathrm{I}_{f}(-15)$ and $\mathrm{I}_{t}(-15)\left({ }^{\circ} \mathrm{Cday}\right)$ & $383(77)$ & $453(66)$ \\
$\mathrm{I}_{f}(-230)$ and $\mathrm{I}_{t}(-230)\left({ }^{\circ} \mathrm{Cday}\right)$ & $164(87)$ & $319(69)$ \\
Length of the frost and thaw season at $-230 \mathrm{~cm}$ (days) & $187(48)$ & $160(20)$ \\
Mean air temperature $\left({ }^{\circ} \mathrm{C}\right)<\mathrm{Ta}>{ }_{f-t}$ & $-3.2(0.4)$ & $1.2(0.3)$ \\
Maximum daily air temperature $\left({ }^{\circ} \mathrm{C}\right) T_{\mathrm{f}-\mathrm{Max}} / \mathrm{T}_{\mathrm{t}-\text { Max }}$ & $2.2(0.7)$ & $5.0(0.3)$ \\
Minimum daily air temperature $\left({ }^{\circ} \mathrm{C}\right) T_{\mathrm{f}-\min } / T_{\mathrm{t}-\text { min }}$ & $-14.4(3.8)$ & $-4.9(2.3)$ \\
\hline
\end{tabular}

The heat loss or gain (equivalent to the ground Enthalpy change) are produced during the time interval defined as, respectively, the period of cooling in the frost season $\left(t_{c f}\right)$, or the period of warming in the thaw season $\left(t_{w t}\right)$ (Fig. 3). Therefore, the average heat flux exchanged by the ground surface during those periods shows the following definition:

$$
\left\langle\Phi_{f-t}\right\rangle=\frac{\Delta \mathrm{H}_{f-t}}{\mathrm{St}_{c f-w t}}=\frac{K D_{f-t}}{\alpha t_{c f-w t}}\left[a \ln D_{f-t}-a-b\right]
$$

The Enthalpy change per unit area $(\Delta \mathrm{H} / \mathrm{S})$ allows to estimate the heat gained or lost by the ground during the ground frost and thaw seasons, and to compare distinct years, while the average heat flux $\left(<\Phi_{f-t}>\right)$ expresses the rates of cooling and warming.

The methodology presented above was used to calculate the values of the ground Enthalpy change $\left(\Delta \mathrm{H}_{f-t} / \mathrm{S}\right)$ and average heat flux $\left.\left(<\Phi_{c f-w t}\right\rangle\right)$. In order to analyse the results obtained, the air $\left(I_{a f-t}\right)$ and ground freezing or thawing indexes $\left(I_{f-t}\right)$ at 15 and $230 \mathrm{~cm}$ depth $\left(I_{f-t}(-15)\right.$ and $\mathrm{I}_{f-t}(-230)$ ) were calculated from the field data. Due to the lack of measurements at $5 \mathrm{~cm}$ depth, the ground freezing and thawing indexes at this level were only calculated for 2004 , for the winter of 2005 and for the summer of 2004-2005. Other measured parameters are: mean (frost or thaw) air temperature $(<\mathrm{Ta}>f-t)$, daily minimum and maximum temperatures $\left(T_{f-t} \min\right.$ and $\left.T_{f-t} \mathrm{Max}\right)$ and length of the frost and thaw seasons (winters of 2000 to 2005 and summers of 2002 to 2005) (Table 2). The incomplete setting of the monitoring devices in 2000 did not allow calculating the Enthalpy and associated parameters for that year.

\section{Results and discussion}

The results show that the ground frost season was around two months longer than the thaw season (Table 2). The exception was 2005 with 183 days for the thaw season and 134 days for the frost season. The length of the frost season shows a standard-deviation of 48 days and a mean value of 187 days. The average air temperatures during the frost season show a value of $-3.2^{\circ} \mathrm{C}$ with daily maximum and minimum temperatures of $2.2^{\circ} \mathrm{C}$ and $-14.4^{\circ} \mathrm{C}$. These contrast with average temperatures during the thaw season of $1.2^{\circ} \mathrm{C}$ and daily maximum and minimum temperatures of $5.0^{\circ} \mathrm{C}$ and $-4.9^{\circ} \mathrm{C}$, respectively (Table 3 ).

The values of the ratio of ground $(15 \mathrm{~cm})$ and air freezing indexes $\left(I_{f t}(-15) / I_{a f-t}\right)$ show large interannual variability and are probably controlled by the snow thickness during the winter (Table 2). As an example of this control, the 2002 and 2005 frost seasons show relatively similar air freezing indexes $\left(1027^{\circ} \mathrm{Cday}\right.$ in 2002 and $1102^{\circ} \mathrm{Cday}$ in 2005). However, the modelled ground-atmosphere energy balance in the frost season was about 3 times larger in 2002 than in 2005. The ratio between the ground and air freezing indexes was also very different, with 0.70 in 2002 and 0.27 in 2005, indicating the buffering effect of the snow cover. The snow seems also to have controlled the length of the frost season, which lasted for 227 days in 2002, but only for 134 days in 2005 (Table 2).

Notwithstanding the small time frame with comparable data between the ground temperature series for frost and thaw seasons, a preliminary analysis of the period of 2003 
Table 4. Net energy balance in the 2003, 2004 and 2005 years.

\begin{tabular}{llll}
\hline Period & $\begin{array}{l}\text { Enthalpy/S }\left(\mathrm{MJ} / \mathrm{m}^{2}\right) . \\
\Delta \mathrm{H}_{f-t} / \mathrm{S} \text { Frost } \\
\text { season }\end{array}$ & $\begin{array}{l}\text { Enthalpy/S }\left(\mathrm{MJ} / \mathrm{m}^{2}\right) . \\
\Delta \mathrm{H}_{f-t} / \mathrm{S} \text { Thaw } \\
\text { season }\end{array}$ & $\begin{array}{l}\text { Enthalpy Balance/S } \\
\left(\mathrm{MJ} / \mathrm{m}^{2}\right)\end{array}$ \\
\hline 2003 & -25.3 & 29.5 & +4.2 \\
2004 & -16.3 & 25.3 & +9.0 \\
2005 & -12.6 & 29.1 & +16.5 \\
\hline
\end{tabular}

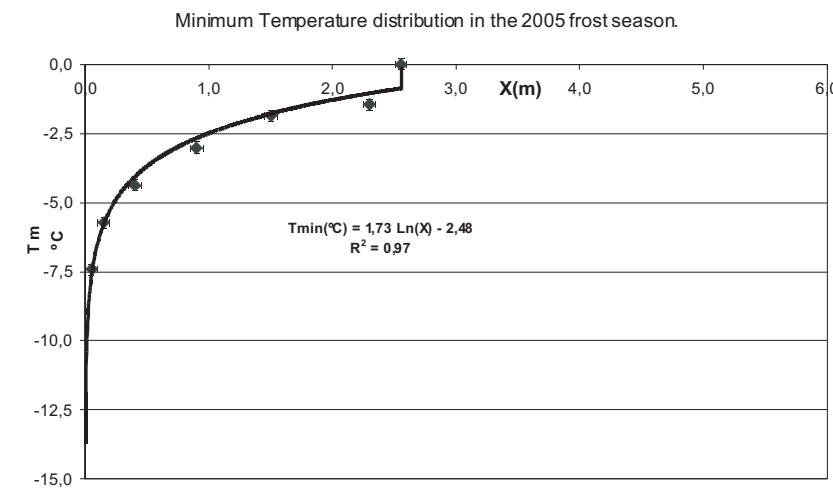

Maximum Temperature distribution in the 2004-05 thaw season.

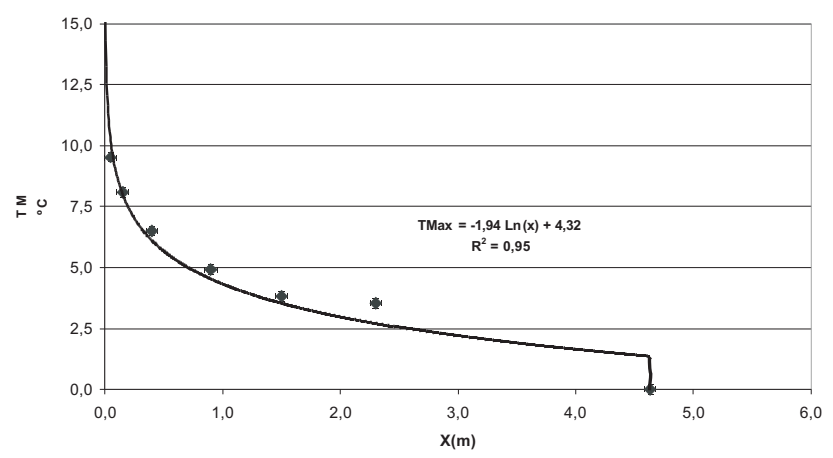

Fig. 5. Temperature profiles at the Incinerador borehole in the frost season of 2005 at the final stages of cooling (minimum temperatures) and thaw season of 2004-2005 and its corresponding logarithmic best-fits. $\Delta \mathrm{H} / \mathrm{S}$ is represented by the area between the logfunction representing $T_{F}(\mathrm{x})=T_{\min / \max }(\mathrm{x})$ and the axis $T_{i}(x)=0^{\circ} \mathrm{C}$ in the $\mathrm{x}$-interval $\left[0, \mathrm{D}_{f-t}\right]$.

to 2005 deserves a closer insight. The differences between the mean annual values are significant in the energy balance, with average losses of $-18.1 \mathrm{MJ} / \mathrm{m}^{2}$ and gains of $28.0 \mathrm{MJ} / \mathrm{m}^{2}$ (Table 3). The same trend is visible in the freezing and thawing indexes at both 5 and $15 \mathrm{~cm}$ depth. In average, the air freezing index in the frost season $\left(<I_{a f}>\right)$ is $871^{\circ} \mathrm{Cday}$, while the air thawing index in the thaw season $\left(<\mathrm{I}_{a t}>\right)$, shows values of $173^{\circ} \mathrm{Cday}$. The large differences that appear between the air and the ground thawing index suggest that one of the more important energy terms and effective mode for the ground to gain energy in summer is through solar radiation.

Despite the energy budget differences between the means of the two seasons, the length of the periods of cooling during the frost season (70 \pm 34 days) and of warming during the thaw season ( $71 \pm 3$ days) is somewhat similar (Table 3 ). It is also significant that the length of the period of cooling $\left(t_{c f}\right)$ in the frost season of 2004 almost tripled the length of the same period in 2002. However, the total energy exchanged was much higher in the winter of 2002 (Table 2).

The absolute value of the heat lost by the ground during cooling in the frost season showed a high interannual variability (Table 2) and was always smaller than the heat gained during warming in thaw season. The difference between both terms of energy lost in the frost and gained in the thaw seasons allow to calculate the net ground energy exchange during the year. The three complete years of record (2003 to 2005) show an increment of net energy flux into the ground (Table 4) with a mean value of $9.9 \mathrm{MJ} / \mathrm{m}^{2}$. Naturally, these $3-$ years of data lack climatic significance and are brought here as an example.

The heat flux during cooling $\left.\left(<\Phi_{c f}\right\rangle\right)$ in the frost season, a parameter that indicates the average rate of cooling during winter, shows also a significant interannual variation. For example, in 2002 its value was ca. 8 times larger than the value in 2004. However, the difference between the maximum estimated depths of the $0^{\circ} \mathrm{C}$ front $\left(D_{f}\right)$ in the two periods is rather small ( $7.2 \mathrm{~m}$ in 2002 and $5.6 \mathrm{~m}$ in 2004). The difference between the energy losses is also very significant $\left(-48.1 \mathrm{MJ} / \mathrm{m}^{2}\right.$ for 2002 in comparison with $-16.3 \mathrm{MJ} / \mathrm{m}^{2}$ for 2004) (Table 2). On the other hand, the average value of heat flux during the cooling in the frost season $\left.\left(<\Phi_{c f}\right\rangle\right)$ is $-3.5 \mathrm{~W} / \mathrm{m}^{2}$ with a standard deviation of $1.5 \mathrm{~W} / \mathrm{m}^{2}$, in contrast with the heat flux during warming in the thaw season that shows a larger value with smaller standard deviation $\left(<\Phi_{w t}>=4.6 \pm 0.5 \mathrm{~W} / \mathrm{m}^{2}\right)$ (Table 3$)$. This indicates that during the study period the summer warming was more regular interannualy. During the winter, interannual snow cover variability is probably the responsible for the higher variability in the apparent heat flux.

The significance of snow cover variability is also visible in the poor control that air temperature alone exert on the 
Freezing and Thawing final temperatures - 2003

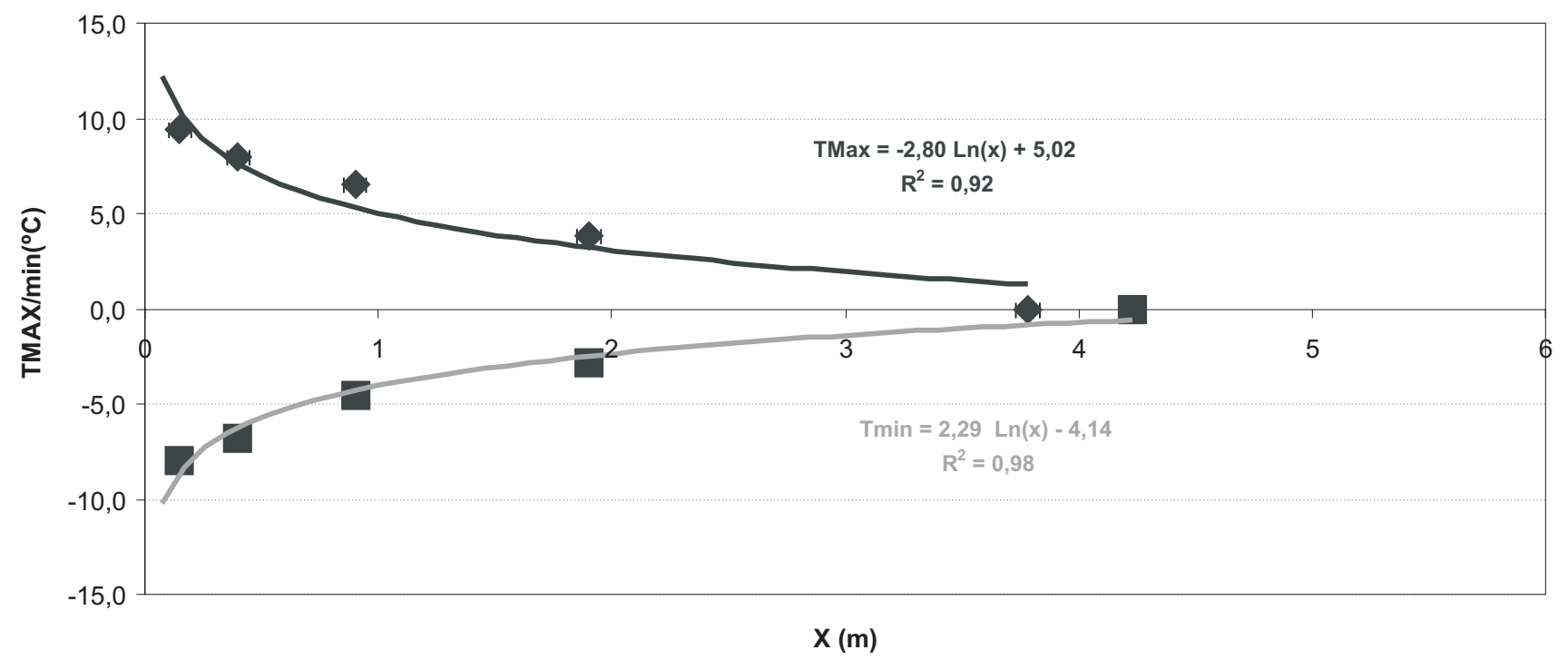

Fig. 6. Temperature profiles at the Incinerador borehole in the thaw seasons of 2003 and 2004, and frost seasons, at the final stages of cooling (minimum temperatures) and warming (maximum temperatures) with its corresponding logarithmic best-fits. The last two points in the graph, below the borehole depth, are extrapolated using Eqs. (10) and (11) and correspond to $\left(D_{f}\right.$ and $\left.D_{t}\right)$ that is the reference depth where the ground heat flux is zero and the temperature is close to $0^{\circ} \mathrm{C}$.

ground heat fluxes. This is clear in Table 2. For example, the mean air temperature during cooling in the frost season of 2001 was significantly higher $\left(-2.3^{\circ} \mathrm{C}\right)$ than the value recorded in $2002\left(-4.2^{\circ} \mathrm{C}\right)$. Nevertheless, the modelled maximum depth of the $0^{\circ} \mathrm{C}$ front was rather similar in both periods. Similarly, no significant correlation was found between the ground Enthalpy change and the average, minimum and maximum air temperatures. Absolute minimum and maximum temperatures in the frost season were $-18.8^{\circ} \mathrm{C}$ and $2.3^{\circ} \mathrm{C}$ in 2005 in contrast with 2002 , with $-15.4^{\circ} \mathrm{C}$ and $3.4^{\circ} \mathrm{C}$. However, the difference in Enthalpy between the 2002 with $-48.1 \mathrm{MJ} / \mathrm{m}^{2}$ and $2005-12.6 \mathrm{MJ} / \mathrm{m}^{2}$ was very important.

\section{Conclusions}

The results of the calculation of the ground Enthalpy balance and average heat fluxes between the active layer and atmosphere boundary layer seem adequate for the study of energy factors influencing the thermal evolution of the active layer in this polar climatic conditions that characterized the study area. The results support the fact that the independent study of air temperature regimes or air freezing indexes is insufficient to characterize the net energy exchanges between the ground surface and the atmosphere, since the later depends also from snow cover thickness, radiation balance, turbulent and sensible heat fluxes and many other factors. All these factors show an extremely variable interannual and non-linear behaviour. The Enthalpy balance method integrates all these factors and reduces error propagation that are in others methods.

The study period of 2003 to 2005 is too short for any climatological significance. However, the results obtained allow some important insights and are stimulating for continuing research. The ground at Incinerador borehole has shown in an annual basis a net energy gain in all the years. Winter energy losses were extremely variable and summer gains showed less variation. This emphasises on the important control of snow cover, since air temperatures did not show a direct control on ground temperature.

Despite the limitations arising from the assumptions used in the modelling approach, we consider that a borehole in bedrock where latent heat exchanges are minimal in an area with the climate characteristics of the Maritime Antarctic is prone to the application of the method of ground Enthalpy change estimation. For this, it is important that every year two distinct periods, one of them with daily ground temperature distribution below $0^{\circ} \mathrm{C}$ (frost season) and the other with temperatures above $0^{\circ} \mathrm{C}$ (thaw season), with nearly isothermal states at $0^{\circ} \mathrm{C}$ occur.

Our current field monitoring programmes are continuing and being improved using sensors for snow thickness monitoring and other meteorological variables, like radiation. These data will be used to study the effect of these parameters in the ground Enthalpy balance. The field validation of the approach presented here will be also analysed in our future research. 


\section{Nomenclature}

\begin{tabular}{|c|c|}
\hline$\alpha$ & Soil thermal diffusivity $\left(\mathrm{m}^{2} / \mathrm{s}\right)$. \\
\hline $\mathrm{K}$ & Thermal conductivity $(\mathrm{W} / \mathrm{mK})$. \\
\hline$\rho$ & Density $\left(\mathrm{kg} / \mathrm{m}^{3}\right)$. \\
\hline $\mathrm{C}$ & Heat capacity $(\mathrm{J} / \mathrm{K})$. \\
\hline c & Specific Heat $(\mathrm{J} / \mathrm{kgK})$. \\
\hline $\mathrm{H}$ & Enthalpy (J). \\
\hline$<\Phi>$ & Average thermal heat flux $\left(\mathrm{W} / \mathrm{m}^{2}\right)$. \\
\hline$\Delta \mathrm{H} / \mathrm{S}$ & Enthalpy variation per surface unit $\left(\mathrm{J} / \mathrm{m}^{2}\right)$. \\
\hline $\mathrm{U}$ & Internal Energy $(\mathrm{J})$. \\
\hline $\mathrm{P}$ & Presion $(\mathrm{Pa})$. \\
\hline $\mathrm{V}$ & Volume $\left(\mathrm{m}^{3}\right)$ \\
\hline$t_{c f}$ & $\begin{array}{l}\text { Period of ground cooling } \\
\text { in the frost season }(\mathrm{s}) \text {. }\end{array}$ \\
\hline$t_{w t}$ & $\begin{array}{l}\text { Period of ground warming } \\
\text { in the thaw season }(\mathrm{s}) \text {. }\end{array}$ \\
\hline$\rho$ & Density $\left(\mathrm{kg} / \mathrm{m}^{3}\right)$ \\
\hline$t$ & Time (s). \\
\hline $\mathrm{x}$ & Spatial coordinate $(\mathrm{m})$, deep into the soil. \\
\hline$D$ & $\begin{array}{l}\text { Reference depth where the soil } \\
\text { heat flux is either zero }(\mathrm{m}) \text {. }\end{array}$ \\
\hline $\mathrm{X}$ & Zero isotherm free boundary layer (m). \\
\hline$I_{a f-t}$ & Air freezing or thawing index $\left({ }^{\circ} \mathrm{Cday}\right)$. \\
\hline$I_{f-t}(-15)$ & $\begin{array}{l}\text { Freezing and thawing index at } \\
(-15 \mathrm{~cm}) \text { deep }\left({ }^{\circ} \text { Cday }\right) .\end{array}$ \\
\hline$<T a>_{f-t}$ & $\begin{array}{l}\text { Mean air temperature in freezing or thawing } \\
\text { seasons }\left({ }^{\circ} \mathrm{C}\right) \text {. }\end{array}$ \\
\hline$T_{t-\mathrm{Max}}$ & Maximum temperature in thawing season $\left({ }^{\circ} \mathrm{C}\right)$. \\
\hline$T_{f-\min }$ & Minimum temperature in freezing season $\left({ }^{\circ} \mathrm{C}\right)$. \\
\hline$m$ and $n$ & $\begin{array}{l}\text { Terms of the linear function fit that shows the } \\
\text { position of zero isothermal front into the soil } \\
(10) \text { and }(11) \text { in }(\mathrm{m} / \mathrm{s}) \text { and }(\mathrm{m}) \text {, respectively. }\end{array}$ \\
\hline$a$ and $b$ & $\begin{array}{l}\text { Terms of the logarithmic adjust function of } \\
\text { the Maximum or minimum soil temperatures } \\
\text { during thaw or frost seasons }(16)\left({ }^{\circ} \mathrm{C}\right) \text {. }\end{array}$ \\
\hline
\end{tabular}

\section{Sub-index}

$\begin{array}{ll}\mathrm{f} & \text { Freezing. } \\ \mathrm{t} & \text { Thawing. } \\ f-t & \text { Freezing or thawing. } \\ c f-w t & \text { Cooling during frost season or } \\ & \text { warming during thaw season. } \\ \mathrm{c} & \text { Cooling. } \\ \mathrm{w} & \text { Warming. } \\ \mathrm{G} & \text { Ground. } \\ \mathrm{i} & \text { Initial state. } \\ \mathrm{F} & \text { Final state. } \\ \min & \text { minimum. } \\ \mathrm{Max} & \text { Maximum. } \\ \min -\text { Max } & \text { minimum or Maximum. }\end{array}$

Acknowledgements. This work was supported by the funding received by the special actions REN2001-5082-ANT and REN2002-1150-E/ANT. The Unidad de Tecnología Marina (UTM) is thanked for the support in data collection.

Edited by: T. Zhang

\section{References}

Anisimov, O. A., Shiklomanov, N. I., and Nelson, F. E.: Global warming and active layer thickness: results from transient general circulation models, Global Planet. Change, 15, 61-67, 1997.

Arche, A., López-Martínez, J., and Martínez de Pisón, E.: Sedimentology of the Miers Bluff Formation, Livingston Island, South Shetland Islandsm, in: Recent Progress in Antarctic Earth Science, edited by: Yoshida, Y., Kaminuma, K., and Shiraishi, K., Tokyo, Terrapub, 357-362, 1992.

Arya, A. P.: Introduction to Micrometeorology. S. P. S. San Diego, International Geophysics Series, 42, 1998.

Bergamín, J. F., Durán, J. J., González-Casado, J. M., and LópezMartínez, J.: Morfología y estructura del basamento precuaternario de la Caleta Española, Peninsula Hurd, Isla Livingston, Boletin de la Real Sociedad Española de História Natural (Sección Geológica), 93 (1-4), 189-196, 1997.

Bockheim, J.: Permafrost distribution in Southern circumpolar region and its relation to the environment: a review and recommendations for further research, Permafrost Periglac., 6, 27-45, 1995.

Bockheim, J.: International Workshop on Antarctic Permafrost and Soils - Final Report, University of Wisconsin, Madison, WI, http://www.soils.wisc.edu/antarcticConf/, 14-18 November 2004.

Deacon, E. L.: Physical processes near the surface of the earth, in "World survey of Climatology, vol. 2: General Climatology", edited by: Flohn, H., Elservier, Amsterdam, 1969.

French, H.: The periglacial environment, Longman, Harlow, 458 pp., 1996.

Goodrich, L. E.: The influence of snow cover on the ground thermal regime, Can. Geotech. J., 19, 421-432, 1982.

Guglielmin, M., Balks, M., Paetzold, R.: Towards an Antarctic active layer and permafrost monitoring network, In Permafrost Proceedings 8th International Conference on Permafrost, edited by: Phillips, M., Springman, S. M., and Arenson, L. U., Zurich, Switzerland, Balkema, Lisse, Rotterdam, 337-341, 2001.

Hauck, C., Blanco, J., Gruber, S., Vieira, G., and Ramos, M.: Geophysical identification of permafrost in Livingston Island, Maritime Antarctica, J. Geophys. Res., 112, F02519, doi:10.1029/2006JF000544, 2007.

Hinkel, K. M., Outcalt, S. I., and Nelson, F. E.: Temperature variation and apparent thermal diffusivity in the refreezing active layer, Toolik lake, Alaska, Permafrost Periglac., 1(4), 265-274, 1990.

Hoelzle, M., Mittaz, C., Etzelmuller, B., and Haebaerli, W.: Surface energy fluxes and distribution models of permafrost in European Mountain areas: an overview of current developments, Permafrost Periglac., 12, 53-68, 2001.

Kane, D. L., Hinkel, M. K., Goering, D. J., Hinzman L. D., and Outcalt, S. I.: Non conductive heat transfer associated with frozen soils, Global Planet. Change 29, 275-292, 2001. 
King, J. C.: Recent climate variability in the vicinity of Antarctic Peninsula, Int. J. Climatol., 14(4), 357-369, 1994.

King, J. C. and Turner, J.: Antarctic Meteorology and Climatology, Cambridge University Press, Cambridge, 114-120, 1997.

King, J. C., Turner, J., Marchall, G. J., Connolley, W. M., and Lachlan-Cope, T. A.: Antarctic Peninsua Variability and its Causes as revealed by Analysis of Instrumental records, in: Antarctic peninsula climate variability, edited by: Domack, E., Leventer, A., Burnett, A., Bindschadler, R., Convey, P., and Kirby, M., Antarctic research series AGU, 79, 17-30, 2003.

Kudryavtsev, V. A., Gaagulya, L. S., Kondratýeva, K. A., and Melamed, V. G.: Fundamentals of frost forecasting in geological engineering investigations, Cold Regions Research and Engineering Laboratory, Hanover, NH, 1974.

Lachenbruch., A. H.: Periodic heat flow in a stratified medium with application to permafrost problems, US Geologycal Survey Bulletin, 1083-A, 1959.

Ling, F. and Zhang, T.: A numerical model for surface energy balance and thermal regime of the active layer and permafrost containing unfrozen water, Cold Reg. Sci. Technol., 38, 1-15, 2004.

López-Martinez, J., Vilapalana, J. M., Martinez De Pisón, E., Calvet J., Arche, A., Serrat, D. and Pallás, R.: Geomorphology of selected areas in Livingstone Island, South Shetland Islands, in: Geología de la Antártida Occidental, edited by: López-Martínez, J., III Congreso Geológico de España, Simposios, T-III, Salamanca, 271-282, 1992.

Marshall, G. J.: Analysis of recent circulation and thermal advection change in the northern Antarctic Peninsula., Int. J. Climatol., 22(12), 1557-1567, 2002.

Oke, T. R.: Boundary layer climates, Methuen and Co, London, 435 pp., 1987.

Outcalt, S. L., Goodwin, C., Weller, G., and Brown, J.: Computer simulation of the snowmelt and soil thermal regime st Barrow, Alaska, Water Resour. Res., 11(5), 709-715, 1975.

Pallàs, R.: Geologia de l'Illa de Livingston (Shetland del Sud, Antàrtida), Del Mesozoic al Present, PhD thesis, Universitat de Barcelona, 1996.

Peel, D. A.: Ice core evidence from the Antarctic Peninsula region, in Climate Science A. D. 1500, edited by: Bradley, R. S. and Jones, P. D., 549-571, Routledge, New York, 1992.

Ramos, M. and Vieira, G.: Active layer and permafrost monitoring in Livingston Island, Antarctica. First results from 2000 and 2001, in: Permafrost - Proc. 8th International Conference on Permafrost, edited by: Phillips, M., Springman, S. M., and Arenson, L. U., Zurich, Switzerland, Balkema, Lisse, Rótterdam, 929933, 2003.

Ramos, M. and Vieira, G.: Variabilidad térmica de la capa activa y evaluación de la energía perdida por el suelo durante el proceso de congelación en la isla Livingston (Antártida), Inviernos 2000, 2001 y 2002, Boletín de la Real Sociedad Española de Historia Natural, (Sec. Geología), 99, 1-4, 83-92, 2004.

Ramos, M., Vieira, G., Gruber, S., Blanco, J. J., Hauck, C., Hidalgo, M. A., Tomé, D., Neves, M., and Trindade, A.: Permafrost and active layer monitoring in the Maritime Antarctic: Preliminary results from CALM sites on Livingston and Deception Islands, US Geological Survey and The National Academies, USGS OF-2007-1047, Short Research Paper 070, doi:10.3133/of20071047, srp070, 2007.
Riseborough, D., Shiklomanov, N., Etzelmüller, B., Gruber, S., and Marchenco, S.: Recent advances in permafrost modelling, Permafrost Periglac., 19, 137-156, 2008.

Romanovsky, V. E. and Osterkamp, T. E.: Effects of unfrozen water on heat and mass transport processes in the active layer and permafrost, Permafrost Periglac., 11, 219-239, 2000.

Scambos, T., Hulbe, C., and Fahnestock, M.: Climate-Induced Ice Shelf Desintegration in the Antarctgic Peninsula, in: Antarctic peninsula climate variability, edited by: Domack, E., Leventer, A., Burnett, A., Bindschadler, R., Convey, P., and Kirby, M., Antarctic research series AGU, 79, 17-30, 2003.

Schön, J. H.: Physical Properties of Rocks, Pergamon Press, London, 582 pp., 1996.

Serrano, E. and López-Martínez, J.: Rock glaciers in the South Shetland Islands, Western Antarctica, Geomorphology, 35, 145$162,2000$.

Simonov, I. M.: Physical geographic description of Fildes Peninsula (South Shetland Islands), Polar Geography, 1, 223-242, 1977.

Stearns, C. R.: Applications of Lettau's theoretical model of thermal diffusion to soil profiles of temperature and heat flux, J. Geophys., Res., 74, 532-541, 1965.

Smith, M. W. and Riseborough, D. W.: Ground temperature monitoring and detection of climate change, Permafrost Periglac., 7, 4, 301-310, doi:10.1002/(SICI) 1099-1530 (199610) 7:4<301:AID-PPP231>3.O.CO;2-R.1996.

Styszynska, A.: The origin of coreless winters in the South Shetlands area (Antarctica), Polish Polar Research, 25, 45-66, 2004.

Turner, J., Colwell, S. R., and Harangozo, S.: Variability of precipitation over the coastal western Antarctic Peninsula from synoptic observations, J. Geophys. Res., 102(D12), 13999-14007, 1997.

Turner, J., Colwell, S. R., Marshall, G. J., et al.: Antarctic climate change during the last 50 years, Int. J. Climatol., 25, 279-294, 2005.

Van Lipzig, N. P. M., King, J. C., and Lachlan-Cope, T. A.: Precipitation, sublimation, and snow drift in the Antarctic Peninsula region from a regional atmospheric model, J. Geophys. Res., 109, 24106-24132, 2004.

Vaughan, D. G. and Doake, C. S. M.: Recent atmospheric warming and retreat of ice shelves on Antarctic Peninsula, Nature, 379(6563), 328-331, 1996.

Vieira, G. and Ramos, M.: Geographic factors and geocryological activity in Livingston Island, Antarctic. Preliminary results, in: Permafrost, edited by: Phillips, M., Springman, S. M., and Arenson, L. U., Proc. of the Eight Int. Conference on Permafrost, 21-25 July 2003, Zürich, 1183-2 1188, Balkema-Swets \& Zeitlinger, Lisse, 2003.

Washburn, A. L.: Geocryology. A survey of periglacial processes and environments, Edward Arnold, London, 1979.

Williams, P. J. and Smith, M. W.: The Frozen Earth. Fundamentals of Geocryology, Cambridge University Press, Cambridge, 1989.

Zhang, T., Osterkamp, T. E., and Stammes, K.: Influence of the depth hoar layer of seasonal snow cover on the ground thermal regime, Water Resour. Res., 32(2), 2075-2086, 1996. 